\title{
Coconut Water as Organic Inhibitor on Corrosion of Low Carbon Steel in 3.5\% NaCl Solution
}

\author{
Ramang Magga $^{1, \mathrm{a}}$, Muhammad Zuchry ${ }^{1 \mathrm{~b}}$ and Yusnaini arifin ${ }^{2, \mathrm{c}}$ \\ ${ }^{1}$ Mechanical Engineering Department, Tadulako University, Soekarno Hatta Km. 9, Palu, 94117, Indonesia \\ ${ }^{2}$ Electrical Engineering Department, Tadulako University, Soekarno Hatta Km. 9, Palu, 94117, Indonesia \\ aramang.magga@untad.ac.id, buchry_kempo@yahoo.com, ${ }^{\mathrm{c}}$ yusnaini.arifin@untad.ac.id
}

\begin{abstract}
Investigating coconut water as inhibitors to protect low-carbon steel from corrosion in $3.5 \% \mathrm{NaCl}$ has been studied by weight loss method. The weight loss of steel was identified by immersion test. The coconut water used was young and old coconut water. The concentration of coconut water, whether young and old, in $3.5 \% \mathrm{NaCl}$ was varied. The results showed that the corrosion rate of steel decreased with increasing coconut water concentration. Furthermore, old coconut water can further reduce the rate of corrosion in mild steel comparing young coconut water.
\end{abstract}

Keywords-coconut water, green inhibitor, low-carbon steel, immersion.

\section{Introduction}

During the last century, low-carbon steel has been widely used in construction, manufacturing, marine and diverse areas of other industrial and engineering purposes. However, increasing resistance corrosion of low-carbon steel in a corrosive environment is challenging [1]. Cathodic protection and addition of a wide variety of the corrosion inhibitors are the basic techniques used to protect steel structure from corrosion [2]. Among these methods, the use of inhibitors is more promising and practical to protect steel from corrosion [3]-[5]. However, the majority of synthetic corrosion inhibitors are expensive and have a negative impact on human health and environment [6].

Based on environmental consideration, recently, many researchers are developing and finding green inhibitors to reduce corrosion [7]-[9]. Several efforts also have been done by the researchers to find green inhibitors on low-carbon steel in acidic and chloride- containing solutions, such as seawater. Seawater can be represented by $\mathrm{NaCl} 3.5 \%$ for research in laboratory aims. Their findings have proved that adding green inhibitors of essential oil of Salvia Aucheri Mesatlantica [10], Retama Retam Extract [11], Sunflower Seed Hull Extract [12], Rosuvastatin Drug [13], and Egg Shell Powder in acidic solutions, such as sulphuric, $\mathrm{HCl}$, and $\mathrm{H} 2 \mathrm{SO} 4$, decreased corrosion rate of low-carbon steel. Moreover, in $\mathrm{NaCl}$ solution as representative of seawater, findings of the green inhibitor of cabbage extract (Brassica Oleracea) [14], Asafoetida extract [15], and Myrmecodia Pedans extract [16], revealed that those green inhibitors protected low-carbon steel from corrosion.

Coconut is the fruit of the coconut palm (Cocos nucifera) that widely grow in a tropical country and used generally as food and drinks [17]. Indonesia is one of a tropical country where coconut has high potential to grow. Up to $75 \%$ of world coconut production is from Indonesia, Philippines, and India [18].

Based on age, coconut consists of two types, namely young or tender and mature coconut. Young or tender and mature coconut aged between $6-8$ months, and 11 - 13 months, respectively. Young coconut generally used as a fresh and delicious drink. Meanwhile, mature coconut usually is harvested to obtain its meat that further processed as coconut oil, coconut butter, and coconut milk. For coconut water of mature coconut, it is not utilized [18]. 
Coconut water is one of coconut part that is consumed by people around the world not only as a beverage but also traditional remedy. Natural form coconut water, raw coconut water, is a refreshing, nutritious and energy drink that is beneficial for health. Coconut water composed of phytohormones, namely Auxin, 1,3- Diphenylurea, and Cytokinin. Kinetin, one of Cytokinin, has been shown to have strong anti-ageing effects on human skin cells and fruitflies [17]. Therefore, this research investigates coconut water from young and mature coconut water as a green inhibitor of low-carbon steel in 3.5\% $\mathrm{NaCl}$.

\section{Research Methodology}

\section{A. Preparation of Coconut Water Solution}

Young and mature coconut water was used as an inhibitor. The inhibitors were dissolved with $3.5 \%$ $\mathrm{NaCl}$ to get solution of desired concentrations. The higher concentration of the solution the more amount of coconut water was added to the solution. The total volume of solution was $500 \mathrm{ml}$ for each coconut water. The amount of coconut water was $100 \%, 75 \%$, $50 \%, 25 \%$, and $0 \%$ of the total volume solution. Each concentrated solution is filled into a container.

\section{B. Preparation of Specimen}

Low-carbon steel samples of the size $25 \times 20 \times 3$ $\mathrm{mm}$ were used for weight loss studies. The samples were cleaned well prior to use. The samples were mechanically grinded and polished by polishing papers. Then, the mechanically polished samples were weighed.

\section{Weight Loss Study}

The mechanically polished and pre-weighed lowcarbon steel of uniform size was suspended in $500 \mathrm{ml}$ solutions with young and coconut water separately. The samples were withdrawn weekly, for 3 weeks, from the test solution, washed thoroughly with aquades, followed by $\mathrm{HCl}$, rewashed aquades, and dried with a stream of air, then reweighed. Based on the weight loss data, the average corrosion rate can be calculated by the following equation:

Corrosion rate $=\frac{K \times W}{A \times T \times D}$
Where: $\mathrm{K}$ is a constant, $\mathrm{T}$ is the time of exposure in hours, A is Area in $\mathrm{cm}^{2}, \mathrm{~W}$ is mass loss in $\mathrm{g}$, and $\mathrm{D}$ is Density in $\mathrm{g} / \mathrm{cm}^{3}$.

\section{Results and Discussion}

\section{A. Immersion Test of Specimens in Young and Old Coconut Water}

The weight loss measurements were obtained at different concentration of green inhibitors, young and mature coconut water. The loss of weight specimens with mature and young coconut water inhibitors are shown in table 1 and table 2 respectively.

Table 1. Weight loss for specimen immersion in mature coconut water as an inhibitor

\begin{tabular}{|c|c|c|c|c|c|}
\hline \multirow{2}{*}{ Period } & \multicolumn{5}{|c|}{ Loss of weight (g) } \\
\cline { 2 - 6 } & $0 \%$ & $25 \%$ & $50 \%$ & $75 \%$ & $100 \%$ \\
\hline 7 & 0.017 & 0.016 & 0.013 & 0.008 & 0.005 \\
\hline 14 & 0.034 & 0.033 & 0.027 & 0.02 & 0.016 \\
\hline 21 & 0.057 & 0.052 & 0.042 & 0.035 & 0.03 \\
\hline
\end{tabular}

Table 2. Weight loss for specimen immersion in young coconut water as an inhibitor

\begin{tabular}{|c|c|c|c|c|c|}
\hline \multirow{2}{*}{ Period } & \multicolumn{5}{|c|}{ Loss of weight (g) } \\
\cline { 2 - 6 } & $0 \%$ & $25 \%$ & $50 \%$ & $75 \%$ & $100 \%$ \\
\hline 7 & 0.024 & 0.023 & 0.02 & 0.015 & 0.013 \\
\hline 14 & 0.049 & 0.048 & 0.041 & 0.032 & 0.027 \\
\hline 21 & 0.076 & 0.073 & 0.066 & 0.057 & 0.042 \\
\hline
\end{tabular}

\section{B. Corrosion Rate in coconut Water Solution}

After immersing the samples in solution with coconut water as inhibitor, for a period of time, the samples were corroded. Corrosion rates in these samples differed in the concentration of coconut water solution, $100 \%, 75 \%, 50 \%, 25 \%$, and $0 \%$. The corrosion rate of these samples occurs in mature coconut water and young coconut water, as green inhibitors. The corrosion rate of the samples in mature coconut water is shown in table 3 , and young coconut water in table 4. 
Table 3. The corrosion rate of the samples in mature coconut water

\begin{tabular}{|c|c|c|c|c|c|}
\hline \multirow{2}{*}{ Period } & \multicolumn{5}{|c|}{ Corrosion Rate (mpy) } \\
\cline { 2 - 6 } & $0 \%$ & $25 \%$ & $50 \%$ & $75 \%$ & $100 \%$ \\
\hline 7 & 4.688 & 4.441 & 3.590 & 2.211 & 1.383 \\
\hline 14 & 4.715 & 4.555 & 3.725 & 2.761 & 2.205 \\
\hline 21 & 5.229 & 4.792 & 3.882 & 3.212 & 2.764 \\
\hline
\end{tabular}

Table 4.The corrosion rate of the samples in young coconut water

\begin{tabular}{|c|c|c|c|c|c|}
\hline \multirow{2}{*}{ Period } & \multicolumn{5}{|c|}{ Corrosion Rate (mpy) } \\
\cline { 2 - 6 } & $0 \%$ & $25 \%$ & $50 \%$ & $75 \%$ & $100 \%$ \\
\hline 7 & 6.618 & 6.383 & 5.523 & 4.146 & 3.596 \\
\hline 14 & 6.796 & 6.625 & 5.656 & 4.418 & 3.720 \\
\hline 21 & 6.972 & 6.727 & 6.101 & 5.231 & 3.869 \\
\hline
\end{tabular}

Table 3 and 4 show that corrosion rate increased as increasing time period of immersion in both solutions of coconut water. The highest corrosion rate occurred in specimen immersed in $0 \%$ coconut water concentration, no coconut water, for both coconut water. On the other hand, specimens immersed in $100 \%$ coconut water experienced the lowest corrosion rates. This phenomenon occurred in mature and young coconut water. These revealed that mature and young coconut can control the corrosion rate of the specimens. In addition, mature coconut water protected the specimens better than young coconut water. Comparison of corrosion rates of the specimens in mature and young coconut solutions can be seen in Figure 1.

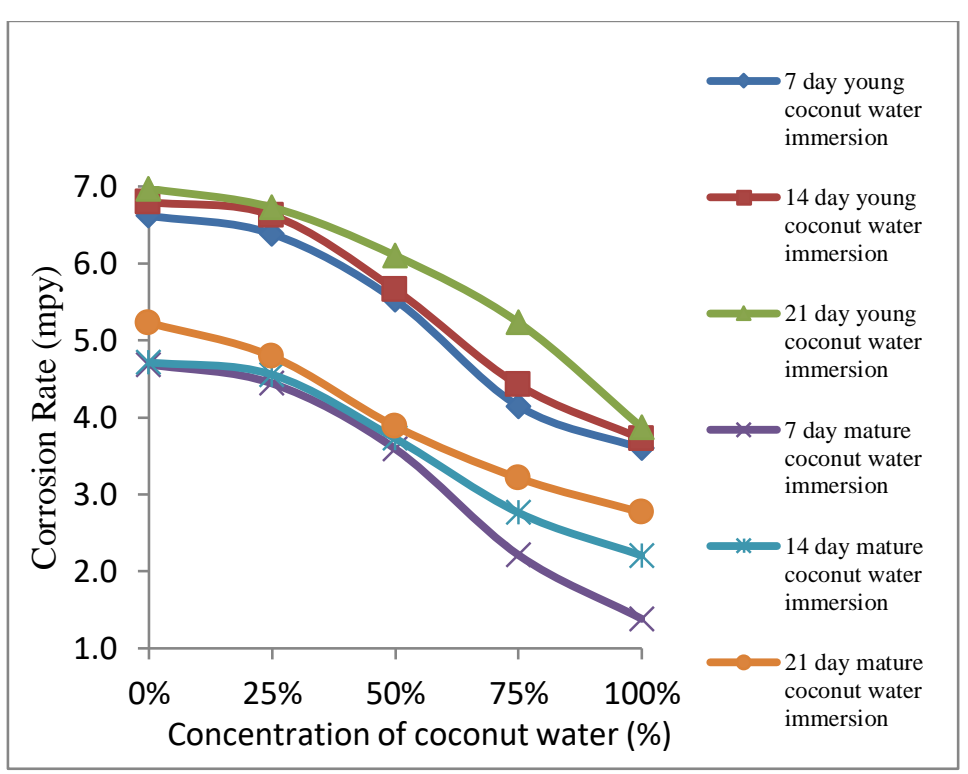

Figure 1. Comparison specimen corrosion rate in various concentration of old and young coconut water solution

\section{Efficiency Inhibitor}

The corrosion rate of mild steel in $3.5 \% \mathrm{NaCl}$ solution at various concentrated coconut water, $0 \%$, $25 \%, 50 \%, 75 \%$, and $100 \%$, was determined after time period of immersion, 7, 14, and 21 days. Comparison values of inhibition efficiencies based on the various time immersion are given in figure 2, 3, and 4. The inhibition efficiency (Ew\%) usingthe weight loss method, was determined by the following relation:

$$
E_{W} \%=\frac{W_{c o r r}-W_{c o r r}(\mathrm{inh})}{W_{\text {corr }}} \times 100 \%
$$

where Wcorr and Wcorr (inh) are the corrosion rates of mild steel in the absence and presence of the coconut water, respectively. 


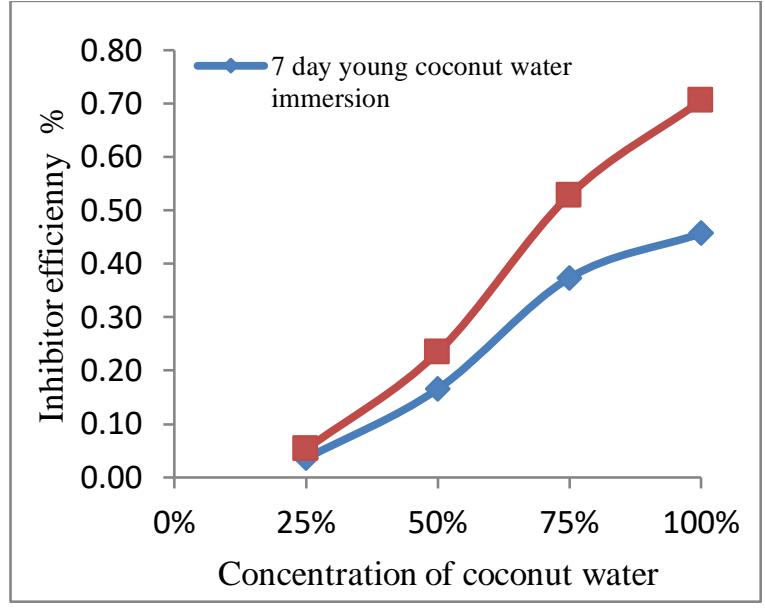

Figure 2. Comparison specimen corrosion rate in various concentration of old and young coconut water solution

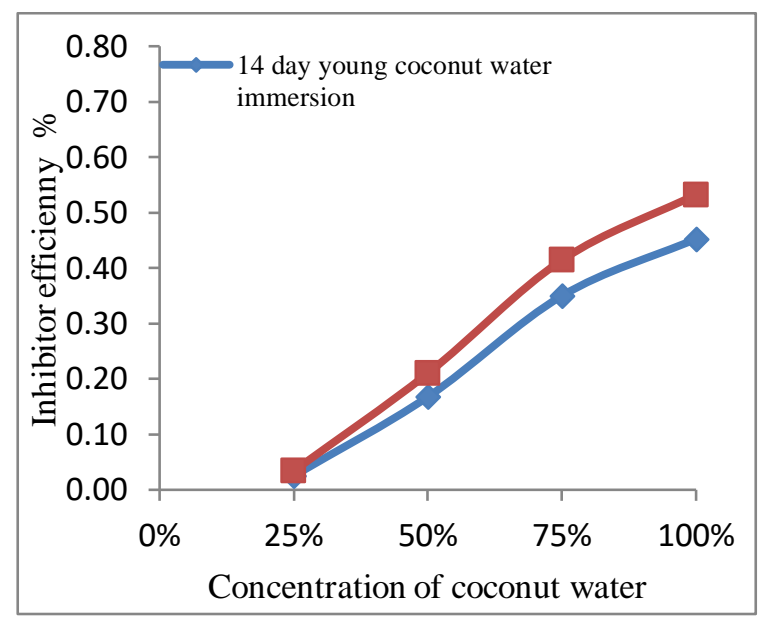

Figure 3. Comparison specimen corrosion rate in various concentration of old and young coconut water solution

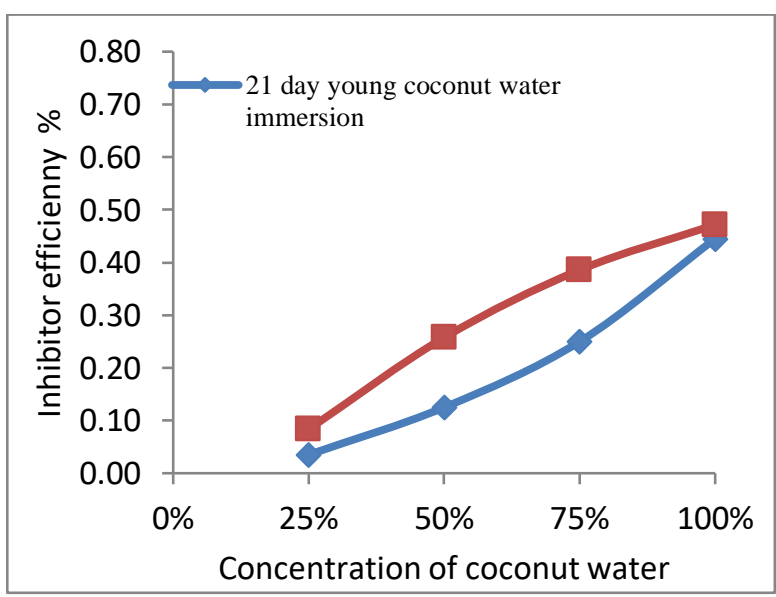

Figure 4. Comparison specimen corrosion rate in various concentration of old and young coconut water solution
From Figures 2, 3, and 4, it can be seen that as concentration of coconut water increases, the value of efficiency inhibition was found increase. Furthermore, mature coconut water inhibitor has higher efficiency than young coconut water. However, the increase of time period immersion, reduced the inhibitor efficiency.

\section{Conclusion}

Coconut water can act as an effective, green and environmentally friendly corrosion inhibitor for lowcarbon steel in $3.5 \% \mathrm{NaCl}$ as:

1. Weight loss of specimens immersed in $3.5 \%$ $\mathrm{NaCl}$ with coconut water as green inhibitor increased with the increasing of immersing period.

2. Coconut water, weather mature and young coconut water, is able to control the rate of corrosion in specimens.

3. Mature coconut water is more able to reduce the rate of corrosion the specimens immersed in the test solution.

\section{Acknowledgement}

The authors would like to express their gratitude to Faculty Engineering of Tadulako University for funding the research. Our gratitude also goes to Eka and M. Rusdi for their contribution in preparation materials and data collection.

\section{References}

[1] S. A. Haddadi, S. A. A. Ramazani, M. Mahdavian, P. Taheri, and J. M. C. Mol, "Fabrication and characterization of graphene-based carbon hollow spheres for encapsulation of organic corrosion inhibitors," Chem. Eng. J., vol. 352, pp. 909-922, 2018, doi: 10.1016/j.cej.2018.06.063.

[2] M. Chigondo and F. Chigondo, "Recent Natural Corrosion Inhibitors for Mild Steel: An Overview," J. Chem., vol. 2016, 2016, doi: 10.1155/2016/6208937.

[3] E. Alibakhshi, E. Ghasemi, and M. Mahdavian, "Sodium zinc phosphate as a corrosion inhibitive pigment," Prog. Org. Coatings, vol. 77, no. 7, pp. 1155-1162, 2014, doi: 10.1016/j.porgcoat.2014.03.027. 
[4] M. J. Palimi, E. Alibakhshi, B. Ramezanzadeh, G. Bahlakeh, and M. Mahdavian, "Screening the anticorrosion effect of a hybrid pigment based on zinc acetyl acetonate on the corrosion protection performance of an epoxy-ester polymeric coating," J. Taiwan Inst. Chem. Eng., vol. 82, pp. 261-272, 2018, doi: 10.1016/j.jtice.2017.10.014.

[5] C. Kamal and M. G. Sethuraman, "Spirulina platensis - A novel green inhibitor for acid corrosion of mild steel," Arab. J. Chem., vol. 5, no. 2, pp. 155-161, 2012, doi: 10.1016/j.arabjc.2010.08.006.

[6] S. A. Haddadi, E. Alibakhshi, G. Bahlakeh, B. Ramezanzadeh, and M. Mahdavian, "A detailed atomic level computational and electrochemical exploration of the Juglans regia green fruit shell extract as a sustainable and highly efficient green corrosion inhibitor for mild steel in 3.5 wt\% $\mathrm{NaCl}$ solution," J. Mol. Liq., vol. 284, pp. 682699, 2019, doi: 10.1016/j.molliq.2019.04.045.

[7] S. T. Arab, "Medicago Sative plant as safe inhibitor on the corrosion of steel in 2. 0M H 2 SO 4 solution," J. Saudi Chem. Soc., vol. 15, no. 1, pp. 73-82, 2011, doi: 10.1016/j.jscs.2010.10.008.

[8] M. A. Quraishi, A. Singh, V. Kumar, D. Kumar, and A. Kumar, "Green approach to corrosion inhibition of mild steel in hydrochloric acid and sulphuric acid solutions by the extract of Murraya koenigii leaves," Mater. Chem. Phys., vol. 122, no. 1, pp. 114-122, 2010, doi: 10.1016/j.matchemphys.2010.02.066.

[9] X. Li, S. Deng, and H. Fu, "Inhibition of the corrosion of steel in $\mathrm{HCl}, \mathrm{H} 2 \mathrm{SO} 4$ solutions by bamboo leaf extract," Corros. Sci., vol. 62, pp. 163-175, 2012, doi: 10.1016/j.corsci.2012.05.008.

[10] M. Znini et al., "Essential oil of Salvia aucheri mesatlantica as a green inhibitor for the corrosion of steel in $0.5 \mathrm{M} \mathrm{H}$ 2SO 4," Arab. J. Chem., vol. 5, no. 4, pp. 467-474, 2012, doi: 10.1016/j.arabjc.2010.09.017.
[11] A. E. K. Benmenine, M. R. Ouahrani, N. Gherraf, M. L. Sekirifa, and L. Baameur, "Anticorrosive action study of retama retam extracts on mild steel X 52 in $20 \% \mathrm{H} 2 \mathrm{SO} 4$ solution," Energy Procedia, vol. 50, pp. 401-405, 2014, doi: 10.1016/j.egypro.2014.06.048.

[12] H. Hassannejad and A. Nouri, "Sunflower seed hull extract as a novel green corrosion inhibitor for mild steel in $\mathrm{HCl}$ solution," J. Mol. Liq., vol. 254, pp. 377-382, 2018, doi: 10.1016/j.molliq.2018.01.142.

[13] M. R. Gholamhosseinzadeh, H. Aghaie, M. S. Zandi, and M. Giahi, "Rosuvastatin drug as a green and effective inhibitor for corrosion of mild steel in $\mathrm{HCl}$ and $\mathrm{H} 2 \mathrm{SO} 4$ solutions," J. Mater. Res. Technol., vol. 8, no. 6, pp. 5314 5322, 2019, doi: 10.1016/j.jmrt.2019.08.052.

[14] M. F. R. Zulkifli, N. M. Radzi, S. M. Jusoh, J. Saidin, and W. M. N. W. Nik, "Potential of cabbage extract (Brassica oleracea) as anti-fouling agent in alkyd undercoat for mild steel in seawater," Malaysian J. Anal. Sci., vol. 23, no. 3, pp. 451-461, 2019, doi: 10.17576/mjas-2019-2303-09.

[15] S. Devikala, P. Kamaraj, M. Arthanareeswari, and S. Pavithra, "Green Corrosion inhibition of mild steel by asafoetida extract extract in $3.5 \% \mathrm{NaCl}$," Mater. Today Proc., vol. 14, pp. 590-601, 2019, doi: 10.1016/j.matpr.2019.04.183.

[16] A. Pradityana, Sulistijono, A. Shahab, L. Noerochim, and D. Susanti, "Inhibition of Corrosion of Carbon Steel in 3.5\% NaCl Solution by Myrmecodia Pendans Extract," Int. J. Corros., vol. 2016, 2016, doi: 10.1155/2016/6058286.

[17] J. W. H. Yong, L. Ge, Y. F. Ng, and S. N. Tan, "The chemical composition and biological properties of coconut (Cocos Nucifera L.) water," Molecules, vol. 14, no. 12, pp. 5144-5164, 2009, doi: 10.3390/molecules14125144.

[18] H. H. Halim et al., "Ergogenic attributes of young and mature coconut (Cocos nucifera 1.) water based on physical properties, sugars and electrolytes contents," Int. J. Food Prop., vol. 21, no. 1, pp. 2378-2389, 2018, doi: 10.1080/10942912.2018.1522329. 